\title{
Fallopia sachalinensis (F.Schmidt) Ronse Decr. (Polygonaceae): a new record for the alien flora of Chile
}

\section{Fallopia sachalinensis (F.Schmidt) Ronse Decr. (Polygonaceae): un nuevo registro para la flora adventicia de Chile}

\author{
Nicol Fuentes ${ }^{1,2^{*}}$, Alicia Marticorena ${ }^{3}$ \& Alfredo Saldaña ${ }^{3}$ \\ ${ }^{1}$ Laboratorio de Invasiones Biológicas (LIB), Facultad de Ciencias Forestales, Universidad de Concepción, Casilla 160-C, \\ Concepción, Chile. \\ ${ }^{2}$ Instituto de Ecología y Biodiversidad (IEB), Casilla 653, Santiago, Chile. \\ ${ }^{3}$ Departamento de Botánica, Universidad de Concepción, Casilla 160-C, Concepción, Chile. \\ *nfuentes@udec.cl
}

\begin{abstract}
RESUMEN
La especie introducida Fallopia sachalinensis (F.Schmidt) Ronse Decr. es registrada por primera vez en el territorio chileno, naturalizada fuera de zona urbanas. Se entrega la descripción taxonómica, características ecológicas de la especie y de la población registrada, así como también la fotografía de ésta. Los especímenes fueron recolectados en ambos costados de la carretera que une la ciudad de Osorno con el aeropuerto Cañal Bajo de la misma ciudad (40³5'55'S; 7303'50"W).
\end{abstract}

This is the second invasive Fallopia taxon recorded in Southern Chile. Fallopia sachalinensis (common name: Giant knotweed), an herbaceous perennial native to East Asia, and has been introduced in several countries (Europe, North America, and Canada) as a garden ornamental plant (Bailey \& Stace 1992, Pyšek \& Prach 1993, Marigo \& Pautou 1998). The species has many of the characteristics of an "ideal invader" (Marigo \& Pautou 1998). Fallopia sachalinensis invades (sensu Richardson et al. 2000) riparian and human-made habitats and often spreads into semi-natural vegetation. It prefers low altitude alluvial plains with a constant flow of water and warm temperatures during the vegetation period of physiological activity (Marigo \& Pautou 1998). The establishment of $F$. sachalinensis is accelerated by human activities. Rhizomes fragments being spread by ploughing and soil transport from one site to another that can serve as a starting point for new populations. Recently, Saldaña et al. (2009) reported Fallopia japonica (Houtt.) Ronse Decr. invades natural environments, but to our knowledge, $F$. sachalinensis has not been reported as invasive plant in Chile. F. sachalinensis is used as ornamental plant in the area recorded (Schilling 1965), and was introduced as fodder plant (Izquierdo 1912). The specimens were collected from a small population of approximately $6 \mathrm{~m}^{2}$ growing at the border of a small water channel on both side of the road without other species around it. The population had individuals from $5 \mathrm{~cm}$ to $2.5 \mathrm{~m}$ high. Some individuals possessed vegetative reproduction. The entire population showed no evidence of foliar and floral herbivory.

\section{TAXONOMY}

The species belongs to the sect. Reynoutria (Houtt.) Ronse Decr., characterized by herbaceous perennial plants, with erect robust stems, well-developed thick rhizomes, large orbicular to broadly ovate leaves with acuminate to cuspidate apices, deeply three-parted styles with fimbriate stigmas, and a functionally dioecious breeding system (Kim \& Park 2000).

Fallopia sachalinensis (F.Schmidt) Ronse Decr. Botanical Journal of the Linnean Society 98(4): 369. 1988. Basionym: Polygonum sachalinensis F.Schmidt, Mém. Acad. Imp. Sci. St.-Pétersbourg Divers Savans 9: 233-234. 1859.

Reynoutria sachalinensis (F.Schmidt) Nakai; $R$. sachalinensis (F.Schmidt) Nakai var. brachyphylla Honda; Tiniaria sachalinesis (F. Schmidt) Janch.

Icon.: Kim \& Park, 2000.

Dioecious herbaceous perennial, rhizomatous, about $2.5 \mathrm{~m}$ high; stems erect, usually clustered, sparingly branched, ascending above, stout, glaucous; ocrea persistent or deciduous, brownish, cylindric, 6-12 $\mathrm{mm}$, margins oblique, face without reflexed and slender bristles at base, otherwise glabrous or puberulent; petiole 1-4 cm, glabrous; leaves 
15-30 x 10-25 cm, ovate-oblong, base cordate, apex acuteacuminate, margins entire, slightly ondulate, glaucous beneath, glabrous, with pluricellular hairs along the veins; flowers in dense and much branched axillar panicles, 3$8 \mathrm{~cm}$ length, inflorescence axes puberulent to pubescent; peduncle $0.1-4 \mathrm{~cm}$ or absent, puberulent to reddishpubescent; pedicels ascending or spreading, articulated proximally, 2-4 mm, glabrous; flowers bisexual or pistillate, 4-7 per ocreate fascicle; perianth accrescent and glabrous in fruit, greenish, 4.5-6.5 mm including stipelike base, glabrous; tepals obovate to elliptic, apex obtuse to acute, outer 3 winged; stamens 6-8; filaments flattened proximally, glabrous; styles connate basally; stigmas fimbriate; achenes included, brown, ovate, cuneateobovate 2.8-4.5 $\times 1.1-1.8 \mathrm{~mm}$, shiny, smooth, wings flat to undulate, $1.8-2.2 \mathrm{~mm}$ wide at maturity, decurrent on stipelike base to articulation, margins entire (Jisaburo 1965, Freeman \& Hinds 2011).

\section{ECOLOGICAL CHARACTERISTICS}

Fallopia sachalinensis has many characteristics that confer the ability to invade the habitats mentioned above; clonal reproductive spread (i.e. vegetative multiplication of rhizomes) associated with an extraordinary high rate of proliferation of rhizomes, abundant leaf cover (Fig. 1a), favourable leaf orientation to capture high light intensity, mechanisms for adaptation to adverse conditions and the use of competitive strategies to monopolize resources (Marigo \& Pautou 1998). Additionally, the hybrid of $F$. sachalinensis with $F$. japonica, $F$. x bohemica has been documented to be twice as an invasive as the parents species, having a more varied genome (Mandak et al. 2004). Among the impact caused by $F$. sachalinensis are the restriction of access to stream and river banks, the damage to flood fence structures, the outcompeting and exclusion of native vegetation, and the decrease of potential vegetation development (Marigo \& Pautou 1998).

The pathway for the introduction (i.e. ornamental) and the date of introduction of $F$. sachalinensis in this area probably was the same of $F$. japonica, which was recently recorded in the same area (Saldaña et al. 2009), because the distance between both records is only $100 \mathrm{~km}$. Therefore, the chances for hybridization by cross-pollination between them are high, because seeds of $F$. japonica may be dispersed beyond $16 \mathrm{~m}$ (Tiébré et al. 2007); and in the case of plants growing next to riverbanks, there is a good chance of hybrid seeds

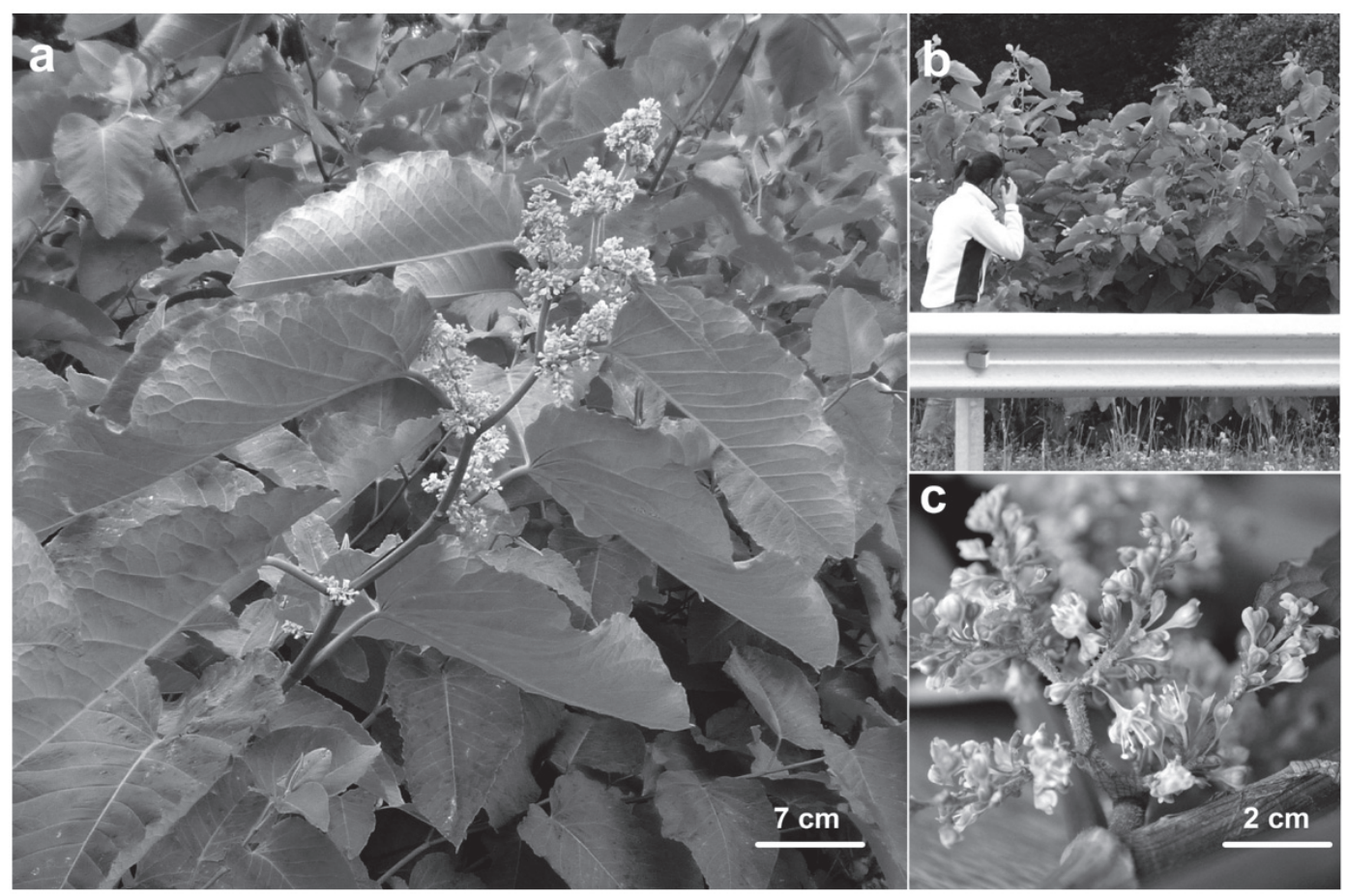

Figura 1. Fallopia sachalinensis. a) Tallos con hojas e inflorescencias axilares. b) Hábito de crecimiento en el sector de recolección. c) Inflorescencia en la antesis (fotografías de N. Fuentes).

Figure 1. Fallopia sachalinensis. a) Branch with leaves and axillar inflorescences. b) Growth habit at the site of collection. c) Axillar inflorescence in anthesis (photographs by N. Fuentes). 
being dispersed downstream for much greater distances. In order to inhibit further invasions and the hybridization between both species, it is necessary to determine the area invaded by $F$. japonica and $F$. sachalinensis, and evaluate the chances and costs of eradication and control. Probably, these species are still on its primary spreading phase, because no other populations were located around the same area. Long-term establishment of a new widespread pest can be avoided using an appropriated eradication program. On the contrary, the high invasion ability of Fallopia taxa will undoubtedly result in occupation of new localities in the near future.

In Chile currently are occurring four species of the genus Fallopia: F. japonica (Saldaña et al. 2009), F. sachalinensis (this report), F. convolvulus (L.) Á.Löve (Matthei 1995), and $F$. baldschuanica (Regel) Holub (cultivated species according to the Herbarium CONC).

Key for Recognition the species of Fallopia Present in Chile

1. Leaves greater than $5 \mathrm{~cm}$ long

2. Leaves 15-30 cm long; base cordate...

F. sachalinensis

2'. Leaves 6-15 cm long; base truncate. F. japonica

1 '. Leaves less than $5 \mathrm{~cm}$ long

3. Annual herbs, perianth green

F. convolvulus

3'. Woody plant, perennial, perianth pink.

F. baldschuanica

\section{Material studied}

CHILE. Región de los Lagos, Prov. Osorno, Aeropuerto Cañal Bajo (40³5'55'S; 7303'50”W), 6-XII-2010, 64 m a.s.1., N. Fuentes (CONC 172756).

\section{ACKNOWLEDGEMENTS}

NF thanks the financial support by Instituto de Ecología y Biodiversidad (IEB) (Project ICM 05-002 and PFB-23). AS acknowledges the financial support by Fondecyt - Iniciación 11090133.

\section{BIBLIOGRAPHY}

Bailey, J.P. \& C.A. StACE. 1992. Chromosome number, morphology, pairing, and DNA values of species and hybrids in the genus Fallopia (Polygonaceae). Plant Systematic and Evolution 180(1-2): 29-52.

Freeman, C.C. \& H.R. Hinds, Flora of North America http://www. efloras.org/florataxon.aspx?flora_id=1\&taxon_id=112640 (Accessed 19 march 2011).

Izquierdo, S. 1912. Catálogo general descriptivo e ilustrado del criadero de árboles de Santa Ines (Nos) Chile. Sociedad imprenta y litografía universo. Chile. $481 \mathrm{pp}$.

Jisaburo, O. 1965. Flora of Japan (in English). Edited by F.G. Meyer \& E.H. Walker. Smithsonian Institution, Washington, D.C. $1067 \mathrm{pp}$.
KIM, J.Y. \& C. PARK. 2000. Morphological and chromosomal variation in Fallopia section Reynoutria (Polygonaceae) in Korea. Brittonia 52(1): 34-48.

Mandák, B., P. Pyšek \& B. Kateřina. 2004. History of the invasion and distribution of Reynoutria taxa in the Czech Republic: a hybrid spreading faster than its parents. Preslia 76: 15-64.

Marigo, G. \& G. Pautou. 1998. Phenology, growth and ecophysiological characteristics of Fallopia sachalinensis. Journal of Vegetation Science 9: 379-386.

Matthei, O. 1995. Manual de las malezas que crecen en Chile. Alfabeta Impresores, Chile.

PYŠEK, P. \& K. PRACH. 1993. Plant invasion and the role of riparian habitats: a comparison of four species alien to central Europe. Journal of Biogeography 20: 413-420.

Richardson, D.M., P. Pyšek, M. Rejmanek, M.G. Barbour, F.D. PANetTA \& C.J. West. 2000. Naturalization and invasion of alien plants: concepts and definitions. Diversity and Distributions 6: 93-107.

Saldaña, A., N. Fuentes \& S. Pfanzelt. 2009. Fallopia japonica (Houtt.) Ronse Decr. (Polygonaceae): A new record for the alien flora of Chile. Gayana Botánica 66: 283-285.

Schilling, P. 1965. Plantas exóticas en cultivo o naturalizadas en Chile. Tesis Ingeniero Agrónomo, Universidad de Chile. Santiago, Chile. 146 pp.

Tiébré, M., S. Vanderhoeven, L. Saad \& G. Mahy. 2007. Hybridization and Sexual Reproduction in the Invasive Alien Fallopia (Polygonaceae) Complex in Belgium. Annals of Botany 99: 193-203.

Recibido: 22.03.11

Aceptado: 22.06.11 